\title{
Chitosan and graphene oxide hybrid nanocomposite film doped with silver nanoparticles efficiently prevents biofouling
}

\section{Saranya Pounraj ${ }^{1}$, Prathap $S^{1}$, and Subhankar Paul ${ }^{1 *}$}

${ }^{1}$ Structural Biology and Nanomedicine Laboratory, Department of Biotechnology and Medical Engineering, National Institute of Technology, Rourkela 769008, Odisha, India.

*Correspondence: Dr. Subhankar Paul, Associate Professor, Structural Biology and Nanomedicine Laboratory, Department of Biotechnology and Medical Engineering, National Institute of Technology Rourkela, Rourkela-769008, Odisha, India. E-mail: spaul@nitrkl.ac.in. Tel: +91-0661-2462284, +91-0661-2463284 (R). Fax: +91-0661-2462022. 


\begin{abstract}
Here, we developed four different hybrid nanocomposite films using graphene oxide nanosheet (GOns), chitosan (Ch) and silver nanoparticles (AgNPs) and explored their inherent inhibitory effect on bacterial biofilm formation (biofouling). Various spectroscopy and electron microscopy results confirmed the doping of AgNPs on GOns-Ch matrix. The wettability study of films also confirmed that GOns-Ch-AgNP nanocomposite film has the highest surface hydrophobicity among all. When Escherichia coli and Bacillus subtilis were grown and biofouling was studied with different nanocomposite films, the silver-doped nanocomposite film was found efficiently inhibited the biofilm formation as evidenced from agar plate, congo red, swarming motility assay as well as electron microscopy imaging. We also observed from the degradation assay that the nanocomposites were pretty stable in solution which also showed ignorable leaching of AgNPs as well as minimum structural deformation of the matrix. Overall, our study clearly proves that AgNP doped GOns-Ch nano-composite (GOns-Ch-AgNP) exhibits anti adhesion and antimicrobial property and might be used as a surface coating material in various industries including marine and health sector industries to restrain biofouling.
\end{abstract}

Keywords: Graphene oxide nanosheets; AgNP doping; Chitosan; Nano-composite film; Antibiofouling activity. 


\section{Introduction}

Microbial contamination and colonization have always been a critical issue in industry that results in equipment damage as well as threat to human health [1-3]. Biofilm formation over the equipment's surface in the industry-and aquatic environment results in the increased maintenance and operational cost [2]. The most common methods presently used for the removal of biofilms in industries are acid/alkaline based chemical detergents treatment, disinfectants [3]. But their efficiency largely depends upon temperature, $\mathrm{pH}$, concentration and time of exposure of the chemicals which are often ineffective and remove only surface growth and unsafe for humans if treated chemicals released in the water bodies as toxic residues [3, 4]. Many microorganisms can attach to surfaces and form biofilms which are protected by a matrix named extracellular polymeric substances (EPS) [3, 5]. Polysaccharides in EPS retain water and prevent biofilm from drying, thus result in greater chances of communication to other species of microbes and create a complex outer matrix [1].

The complex structure of EPS matrix does not allow disinfectants or chemicals to penetrate deeply inside the matrix which results failure in biofilm suppressing methodology. Although the physical removal is the widely used method to combat with the defense strategy of the EPS layer but the major problem is that bacteria can redeposit in any other surface and started forming biofilm again. Also, it is expensive to maintain and operate equipment system separately for biofilm control [6]. Therefore, the necessity for the development of new and efficient method for preventing biofilm over surfaces has loomed. Recently, antimicrobial coatings have been emerged to control and combat infectious microorganisms over surfaces [7]. The advances in the 
area of material science and nanotechnology are the driving force to promote multi approach antimicrobial coatings to prevent biofouling [8].

Chitosan is a biocompatible agent and most abundant polymer having a strong antibacterial activity along with extraordinary non-toxic effect $[9,10]$. Moreover, it has been used in numerous applications such as in food, textile, biomedicine, wastewater treatment, and cosmetics industries as films, hydrogels and membranes [11-15]. However, chitosan has poor strength and structural stability that results in its limited application in industries as coating materials, and hence to overcome the limitation of chitosan as coating materials, chitosan could be reinforced with graphene oxide nano-sheets (GOns) well known for its mechanical strength, large surface area, high adsorption capacity and antibacterial activity which could be an added advantage to improving not only strength and stability but also the antibacterial properties of chitosan for its application as an industrial coating material to obstruct bio-fouling [16-21]. Furthermore, chitosan contains abundant hydroxyl and amino groups which strongly binds to the oxygen of GOns and improves physical as well as mechanical strength of the composite film [22]. Moreover, silver nanoparticles (AgNPs) well known for its antimicrobial properties has been used as a doping agent to improve the antimicrobial properties of nanocomposite coating material [23-25].

In our present communication, different nanocomposites were developed using graphene oxide nano sheet (GOns), chitosan (Ch) and doped silver nanoparticles (AgNPs) by a cost-effective and environmentally safe method and their inhibitory potential to biofilm formation by bacteria such as Escherichia coli (Gram-negative) and Bacillus subtilis (Gram-positive) was assessed. 


\section{Materials and Methods}

\subsection{Materials}

Graphite powder, chitosan, sodium nitrate $\left(\mathrm{NaNO}_{3}\right)$, silver nitrate $\left(\mathrm{AgNO}_{3}\right)$, sodium hydroxide $(\mathrm{NaOH})$, starch, potassium permanganate $\left(\mathrm{KMnO}_{4}\right), 30 \%$ hydrogen peroxide $\left(\mathrm{H}_{2} \mathrm{O}_{2}\right)$, concentrated sulfuric acid $\left(\mathrm{H}_{2} \mathrm{SO}_{4}\right)$, hydrochloric acid $(\mathrm{HCl})$, congo red, Coomassie brilliant blue R-250 stain, nutrient agar, Luria broth, glucose, crystal violet, ethanol and glutaraldehyde were purchased from Hi-media, India. The chemicals used in all experiments were of analytical grade. All glass wares were purchased from borosil, India. Centrifuge tubes and micropipette tips used were purchased from Tarsons, India.

\subsection{Preparation of Graphene oxide nanosheets}

Graphene oxide nanosheets (GOns) were prepared by modified Hummer's method through oxidation and exfoliation of GOns [26]. Graphite powder of $1 \mathrm{~g}$ and $\mathrm{NaNO}_{3}$ of $0.5 \mathrm{~g}$ were dissolved in $23 \mathrm{ml}$ of concentrated $\mathrm{H}_{2} \mathrm{SO}_{4}$ under stirrer. After $1 \mathrm{~h}, 3 \mathrm{~g}$ of $\mathrm{KMnO}_{4}$ was added at a temperature below $20^{\circ} \mathrm{C}$ and stirring was continued for about $2-3 \mathrm{~h}$ for complete oxidation, which was followed by the addition of $46 \mathrm{ml}$ of distilled water with continuous stirring for $30 \mathrm{~min}$. Finally, it was diluted with distilled water followed by the addition of $10 \mathrm{ml} 30 \% \mathrm{H}_{2} \mathrm{O}_{2}$ solution to stop the reaction. The sample was allowed to settle down and washed with $10 \%$ concentrated $\mathrm{HCl}$ to remove metal ions. The supernatant obtained after centrifugation was sonicated for the exfoliation of graphene layers to monolayer GOns. 


\subsection{Synthesis of silver nanoparticles (AgNPs)}

The preparation of silver nanoparticles (AgNPs) was carried out using $\mathrm{AgNO}_{3}$ as precursor and starch as reducing as well as capping agent as described by previously reported method [27]. Further, $1 \%(\mathrm{w} / \mathrm{v})$ of aqueous soluble starch was maintained at $70^{\circ} \mathrm{C}$ with continuous stirring and $\mathrm{AgNO}_{3}$ solution was added to the starch solution to achieve $1 \mathrm{mM}$ final concentration. Then, $\mathrm{NaOH}$ was added to the reaction mixture and the reaction mixture was kept under stirring till the solution color turns dark yellow which confirms the formation of silver nanoparticles (AgNPs).

\subsection{Preparation of colloidal composite solutions and films}

The composite solutions with respective concentration of various components were prepared by mixing them under magnetic stirring and sonicated them to form well dispersed composites. We prepared GOns-Ch (1:1), GOns-AgNPs (0.01\% doped in GOns), Ch-AgNPs $(0.01 \%$ doped in Ch) and GOns-Ch-AgNP (0.01\% AgNP doped in GOns-Ch) stable colloidal composite solutions. Chitosan (1\%) solution was prepared in $0.1 \mathrm{M}$ acetic acid solution. We carried out a drop-casting method to prepare all the films [28, 29].

\subsection{Characterizations of nano-composites}

UV-visible absorption spectra were recorded using Perkin-Elmer (Lambda 35) spectrophotometer in the range of $200-800 \mathrm{~nm}$ with a scan speed of $240 \mathrm{~nm} / \mathrm{min}$. The size and morphological aspects of GOns and AgNP were analyzed using Transmission Electron Microscope imaging (TEM, Model CM 200). X-ray diffraction (XRD) patterns were analyzed (Rigaku make X-ray diffractometer with monochromatic $\mathrm{CuK} \alpha$, radiation $\lambda=1.5406 \mathrm{~A}^{0}$ ) in the range of $5^{\circ}$ to $80^{\circ}$ at a scan rate of $5^{\circ}$ per min. Fourier transform infrared (FTIR) spectra were 
recorded (Perkin-Elmer FTIR) in the range of wavenumber $4000-400 \mathrm{~cm}^{-1}$. The degree of hydrophobicity of the films was calculated using Kruss CA apparatus for static water contact angle (CA) measurement. The tensile properties of the casted films (dimension $=20 \mathrm{~mm} \times 10$ $\mathrm{mm} \times 0.03 \mathrm{~mm}$ ) were measured with the help of super Duper Multi-National Conglomerates ultimate tensile testing machine (UTM) at a temperature of $18^{\circ} \mathrm{C}$. The morphology of the composite films and bacterial attachment over composite films were analyzed using Bruker made Nova nanosem Field Emission Scanning Electron Microscopy (FESEM).

\subsection{Anti-biofouling assay}

The ability of all the nano-composite films to inhibit the formation of bacterial biofilm was investigated using agar plate assay, congo red assay and swarming motility assay against biofilm forming gram-negative Escherichia coli and gram-positive Bacillus subtilis. The strains were cultured in LB broth and grown statically overnight at $37^{\circ} \mathrm{C}$ until it reached the $\mathrm{OD}_{@_{6000 \mathrm{~nm}}}$ of 0.6 .

\subsubsection{Agar plate assay}

The agar base of $15 \mathrm{~g} / \mathrm{L}$ mixed with $\mathrm{LB}$ medium was autoclaved. After cooled down to $50^{\circ} \mathrm{C}$, the agar solution was poured into petri dish and allowed to solidify at room temperature. The solidified agar surface was plated with $50 \mu \mathrm{L}$ of bacterial of $\mathrm{OD}_{@ 0.6}($ E.coli and B.subtilis). The individual and composite films were placed over the spread culture and incubated at $37^{\circ} \mathrm{C}$ for $24 \mathrm{~h}$. 


\subsection{Congo red agar plate assay}

The formation of the bacterial biofilm over nanocomposite was detected by studying the morphology of fimbriae in E.coli and B.subtilis. overnight culture of $1 \mu \mathrm{L}\left(\mathrm{OD}_{@_{600}}=0.6\right)$ of the bacteria was spotted on the centre of the nanocomposite film and placed over congo red agar plate (15 g/L LB agar, $20 \mu \mathrm{g} / \mathrm{ml}$ Congo red, $10 \mu \mathrm{g} / \mathrm{ml}$ Coomassie brilliant blue mixed in $20 \mathrm{~g} / \mathrm{L} \mathrm{LB}$ medium) and incubated at $37^{\circ} \mathrm{C}$ for $48 \mathrm{~h}$ for the assessment of fimbriae formation over the surface of the film confirms the bacterial biofilm formation.

\subsection{Swarming motility assay}

The surface translocation of the flagellated bacteria is very important for primary attachment and succeeding for the biofilm formation which was assessed by swarming motility assay [30]. In order to assess the effectiveness of the composite films over swarming motility of the bacteria, films were placed onto the center of the LB agar plate $(0.5 \%)$ supplemented with glucose $(0.8 \%)$. Overnight cultured (OD600 $=1)$ bacteria of $1 \mu \mathrm{L}$ were spotted over the centre of the films and incubated at $37^{\circ} \mathrm{C}$ for $24-48 \mathrm{~h}$ to observe the swarm pattern of the bacteria.

\subsection{In vitro biofilm static assay}

The effectiveness of the films for the biofilm inhibition over its surface was assessed by an indirect biofilm static assay. Briefly, $5 \mathrm{ml}$ of diluted overnight culture was added to each test tube with the autoclaved composite films of $2 \times 1 \mathrm{~cm}$ and incubated at $37^{\circ} \mathrm{C}$. After $48 \mathrm{~h}$, test tubes were washed using Millipore water was used to remove the unattached cells from the walls of the test tube. Biofilms formed over the walls of the test tubes were stained with $0.1 \%$ crystal violet dye for 15 min followed by washing to remove excess dye. After $1 \mathrm{~h}$ of drying, 
$80 \%$ ethanol was used to dissolve the dye-stained by the cells and absorbance was measured by a UV-visible spectrophotometer at $\mathrm{OD}_{@ 595}$ which is directly proportional to the amount of biofilm formed by the bacteria. The lower the OD, the lesser would be the biofilm formation.

\subsection{Anti-adhesion property of nanocomposites}

To assess the ability of the films to inhibit bacterial adhesion and colonization, biofilm formation of E.coli and B.subtilis over the surface of the composite film was investigated by electron microscope imaging. The films were incubated inside the bacterial culture and washed with Phosphate Buffered Saline (PBS) to remove the unattached cells. But the attached cells were fixed using glutaraldehyde and dehydrated using different concentrations of ethanol and dried overnight to visualize bacteria.

\section{Results and discussion}

\subsection{Preparation and Characterization of GOns and AgNP}

GOns and AgNP were synthesized as per the protocol described in 'Materials and Methods' section and characterized by TEM, XRD and UV-Vis spectroscopy. TEM image of transparent single layer GOns (Fig. 1A) along with SAED pattern indicates the hexagonal pattern which confirms the monocrystalline nature (001 planes) of the GOns (Fig. 1B) [31].

The XRD spectra of GOns film showed a characteristic peak around $8.81^{\circ}$ and the interlayer distance (d-spacing) of $1.03 \mathrm{~nm}$ which indicated exfoliation of GOns (Fig. 1C) [32]. The UVVis spectra of GOns shows a sharp absorption peak at $230 \mathrm{~nm}$ and a shoulder peak at around $300 \mathrm{~nm}$, which are attributed to $\pi-\pi{ }^{*}$ transition of $\mathrm{C}=\mathrm{C}$ bond and $\mathrm{n}-\pi^{*}$ transition of $\mathrm{C}=\mathrm{O}$ bond, respectively [26, 33] (Fig. 1D). 
The electron microscopic image of synthesized AgNP revealed that particles were spherical in shape with size around 10-15 $\mathrm{nm}$ (Fig. 1E). The patterns of SAED were indexed according to (111), (200), (220) and (311) reflections of FCC silver crystal which is consistent with the XRD pattern of AgNP (Fig. 1F) [34]. AgNP showed XRD peaks at $38.3^{\circ}, 45.3^{\circ}, 64.4^{\circ}$, and $77.95^{\circ}$ were assigned to (111), (200), (220), and (311) crystallographic planes of face-centered cubic AgNPs which matched with the JCPDS silver file No. 04-0783 (Fig. 1G) [35]. The UV-Vis spectra of AgNP depicted a typical surface plasmon resonance (SPR) band at $412 \mathrm{~nm}$ because of the collective oscillation of AgNP electrons in resonance to the incident light wave which clearly indicates the formation of AgNP (Fig. 1H) [34]. 

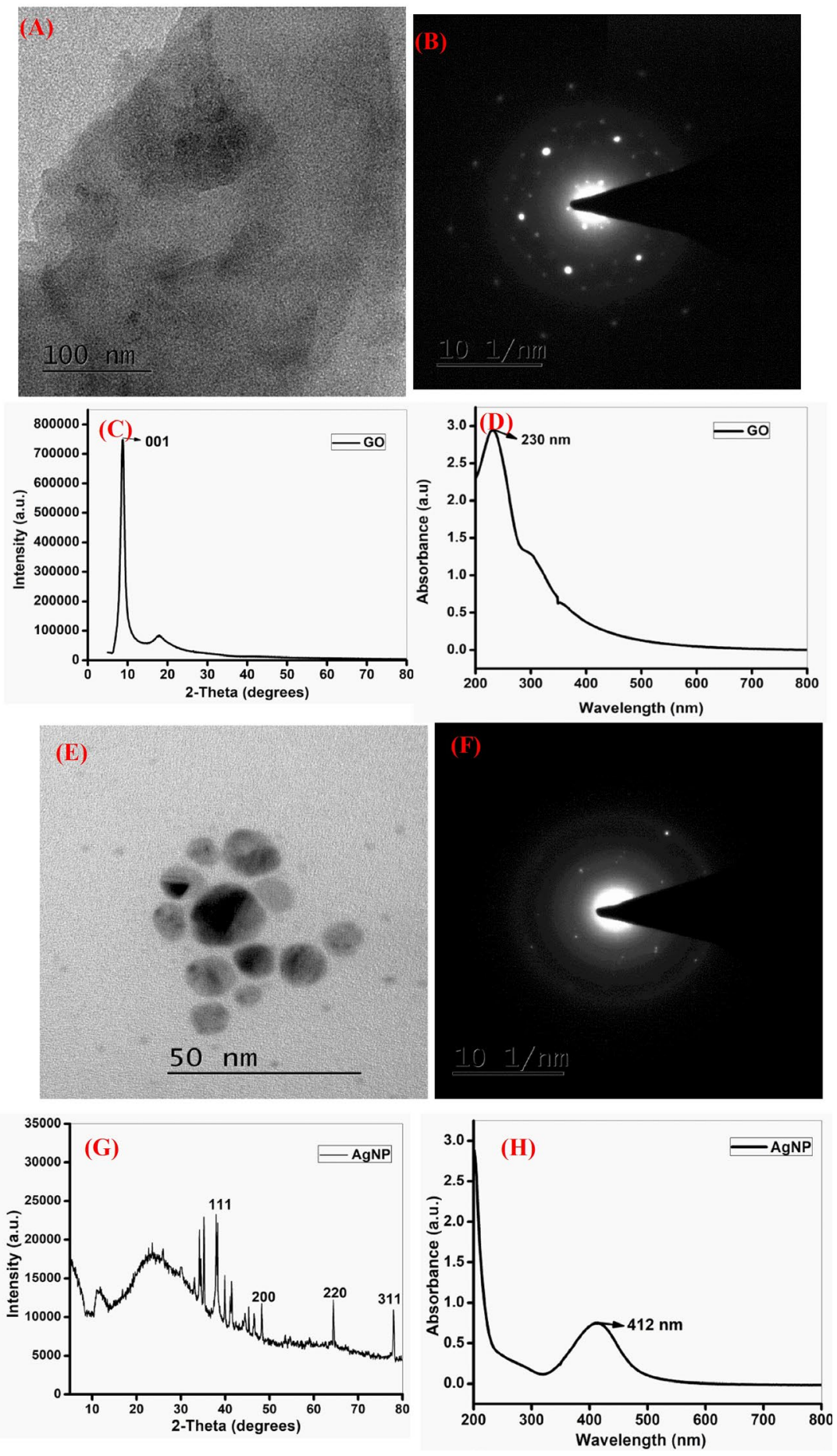

Figure 1. Characterization of GOns by A) TEM image B) SAED pattern C) XRD pattern and D) UV-Vis spectra. Characterization of AgNP by E) TEM image F) SAED pattern G) XRD pattern and $\mathrm{H}) \mathrm{UV}-\mathrm{V}$ is absorption spectra. 


\subsection{Preparation and characterization of nanocomposites films}

(A)
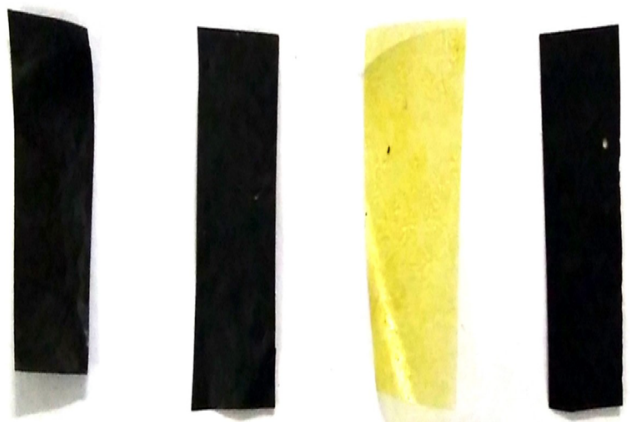

G0ns-Ch G0ns-AgNP Ch-AgNP G0ns-Ch-AgNP

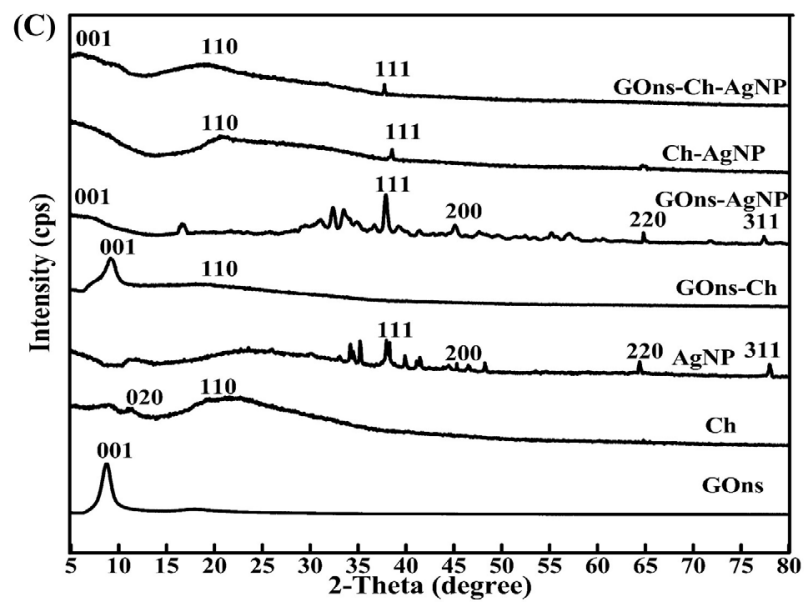

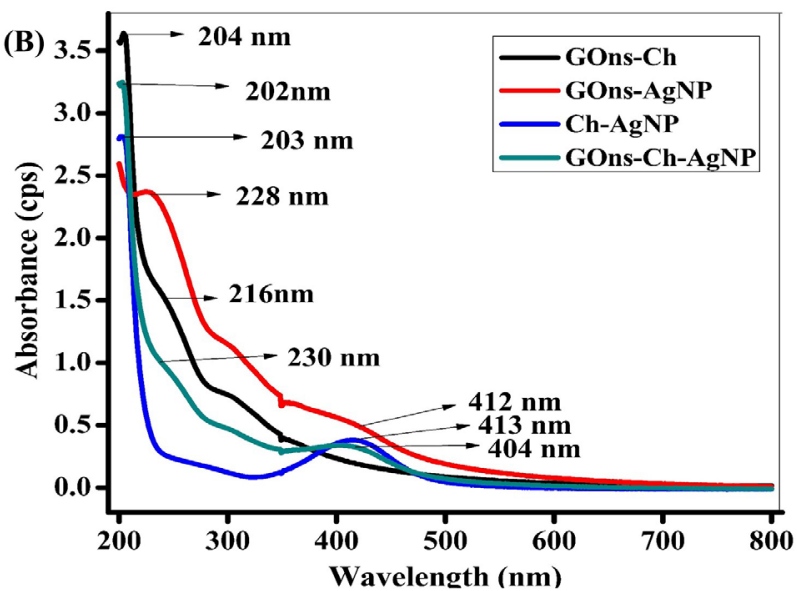

(D)

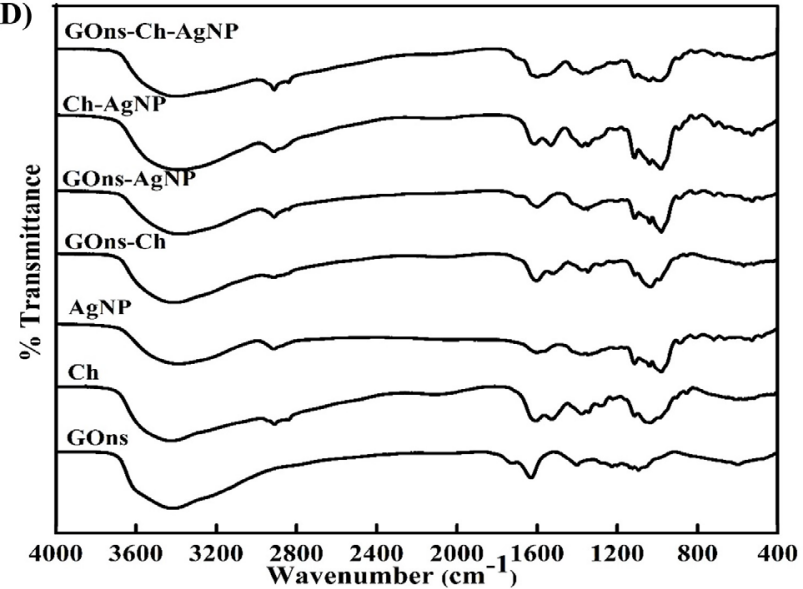

Figure 2. A) Photographic images of various nanocomposites films. B) UV-Vis absorption spectra. C) XRD pattern, D) FTIR spectra of these nanocomposites.

The nanocomposites films were fabricated by drop casting method (Fig. 2A and Fig. S1). The AgNP dispersed nanocomposites (GOns-AgNP, GOns-Ch-AgNP, and GOns-Ch-AgNP) showed absorption peaks at 412, 413 and $404 \mathrm{~nm}$, respectively, revealed the presence of AgNPs in nanocomposites samples (Fig 2B) [3]. However, after the addition of AgNPs to GOns-Ch, blue shift by $8 \mathrm{~nm}$ was observed which is perhaps due to an etching process resulted in producing further reduction in the size of AgNPs [36]. The GOns-Ch solution showed two absorption 
peaks at $204 \mathrm{~nm}$ and $216 \mathrm{~nm}$ which were consistent with the absorption peak of GOns solution (Fig. 3B). The presence of nanoparticles and polymer solution in GOns-Ch was confirmed by XRD measurement which showed a peak at $9.15^{\circ}(001)$ and a broadened peak (110) (Fig. 2C) [37]. The intercalation of silver nanoparticles prevents the regular stacking of GOns layers in GOns-AgNP film resulted in broadened 001 patterns of GOns but the FCC planes $(111,200$ and 220) of AgNP were clearly noticed [35]. The silver nanoparticles immobilized in chitosan showed 111 planes of AgNP along with the 110 plane of chitosan clearly exhibited the impregnation of AgNP in the chitosan matrix. The GOns-Ch-AgNP film showed 001 planes of GOns in addition to 110 and 111 planes of Chitosan and AgNPs [3].

FT-IR spectra of all the individual components and nano-composites were rerecorded (Fig.2D). For GOns, an intense peak was observed at $3414 \mathrm{~cm}^{-1}$ which correspond to the $\mathrm{OH}$ bond. The strong peak at $1630 \mathrm{~cm}^{-1}$ related to the stretching vibrations of $\mathrm{C}=\mathrm{O}$, carboxylic moieties and other peaks at $1400.84,1227.49$ and $1094 \mathrm{~cm}^{-1}$ were corresponded to $\mathrm{C}-\mathrm{O}-\mathrm{H}$ deformation, $\mathrm{C}-\mathrm{H}$ stretching (epoxy groups), and $\mathrm{C}-\mathrm{O}$ stretching vibrations (alkoxy groups), respectively (Fig. 3C). Thus, overall FT-IR spectra confirmed the formation of GOns with the abundance of hydroxyl groups and oxygen groups on its surface [26]. The characteristic absorption bands of chitosan were observed at 3437.12 (O-H stretching vibrations), 2924 (C-H stretching vibrations), 1640 ( $\mathrm{N}-\mathrm{H}$ bending vibrations), 1415 (C-N stretching vibrations) and a band at $1076.44 \mathrm{~cm}^{-1}(\mathrm{C}-\mathrm{O}-\mathrm{C}$ and $\mathrm{C}-\mathrm{O}$ stretching vibrations). The characteristic band for AgNPs appeared at $3396 \mathrm{~cm}^{-1}(\mathrm{O}-\mathrm{H}$ stretching), $2927 \mathrm{~cm}^{-1}$ and $1632 \mathrm{~cm}^{-1}$ (C-H stretching and O-H stretching attributed to the tightly bound water presented in the starch molecule), $1384 \mathrm{~cm}^{-1}$ (C-H bending vibration), $1154 \mathrm{~cm}^{-1}$, $1080 \mathrm{~cm}^{-1}$ and $1023 \mathrm{~cm}^{-1}$ (C-O-C ether stretching vibration in glucose bonds, $577 \mathrm{~cm}^{-1}$ (C-H bending) [5]. In GOns-Ch composite, the appearance of $2927 \mathrm{~cm}^{-1}$ (C-H stretching) of chitosan 
was noticed along with the other vibrations in GOns which confirmed the blending of chitosan with GOns. All the AgNP impregnated films showed C-H bending and C-O-C ether stretching in AgNP spectrum which confirmed the impregnation of AgNP in the nanocomposites. GOns-ChAgNP and Ch-AgNP composites showed characteristics $\mathrm{C}-\mathrm{H}$ and $\mathrm{C}-\mathrm{N}$ stretching observed in the spectrum of chitosan which further confirmed the presence of chitosan in the composite.

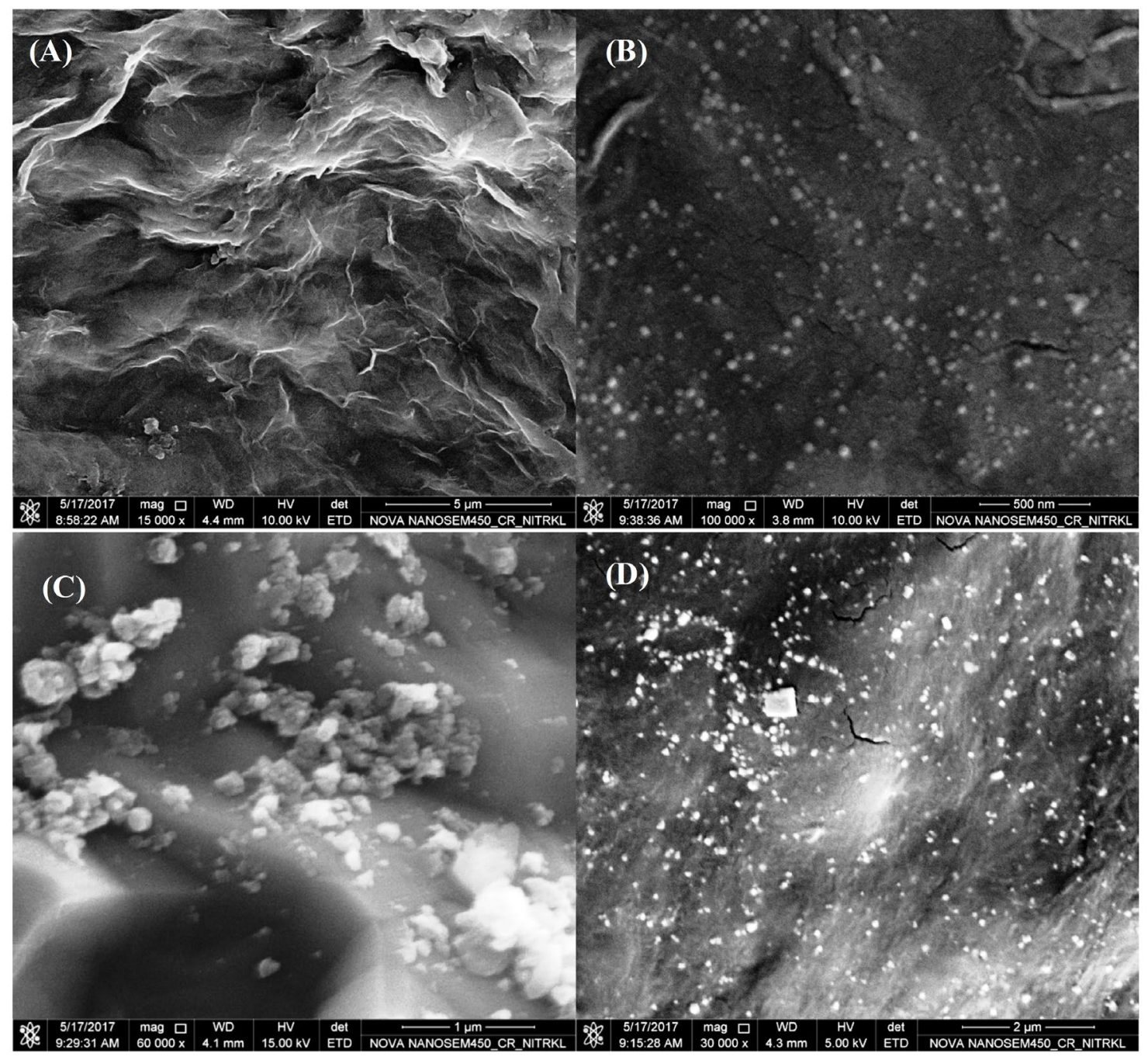

Figure 3. FESEM images of prepared nano-composite films A) GOns-Ch, B) GOns-AgNP, C) Ch-AgNP and D) GOns-Ch-AgNP 
The surface morphologies of the composite films were analyzed by FESEM imaging. In GOnsCh film, the formation of amide linkages between GOns and chitosan made GOns dispersed uniformly in the chitosan matrix and it was seen as rough white chitosan layer over the transparent GOns (Fig.3A) [29]. The aggregation of AgNPs over the chitosan matrix resulted in the clumping of AgNPs over the smooth surface of chitosan (Fig. 3C). Unlike GOns-Ch, numerous white spots were observed on the surface of the GOns-AgNP and GOns-Ch-AgNP composites (Fig. 3 B\&D) confirming the presence of AgNPs over the surface of the composite and also proved that GOns matrix prevented aggregation of AgNPs [38].

\subsection{Physical properties of the composite films}

\subsubsection{Contact angle (CA) measurements}

The nature of surface plays an important role in inhibition of bacterial attachment over its surface during the biofilm formation [39, 40]. The anti-adhesion characteristics of the films usually increase with the increase in surface hydrophobicity which can be measured by the contact angle of water over the surface of the films. Here, the GOns-Ch composite exhibited the highest contact angle $\left(106.55^{\circ}\right)$ among the other composites due to the interaction between GOns and Ch. Following GOns-Ch, GOns-Ch-AgNP and Ch-AgNP films showed hydrophobicity of $101.27^{\circ}$ and $100.015^{\circ}$ (Fig. 4A). Whereas, the absence of chitosan in the GOns-AgNP film made it less hydrophobic (It showed a contact angle $58.115^{\circ}$ ) than other composite films which might make the bacterial attachment over its surface was easier [31]. Indeed, it was already reported that for the surface of polymeric materials, the contact angle within $40-70^{\circ}$ with water (which imparts more a hydrophilic character to the material) enhanced cell adhesion and growth [39]. 
(A)

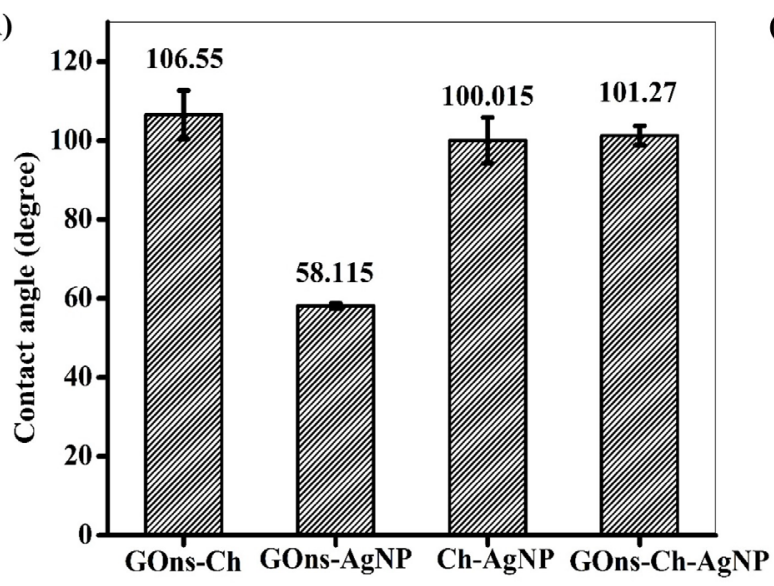

(C)

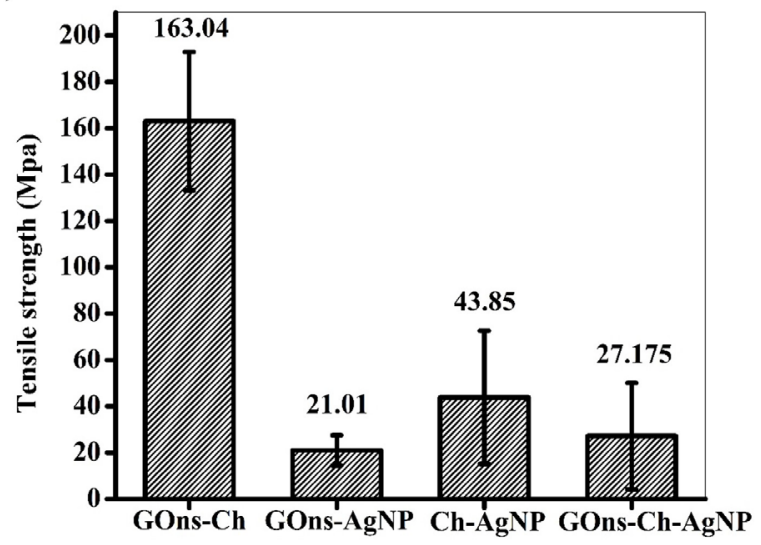

(B)

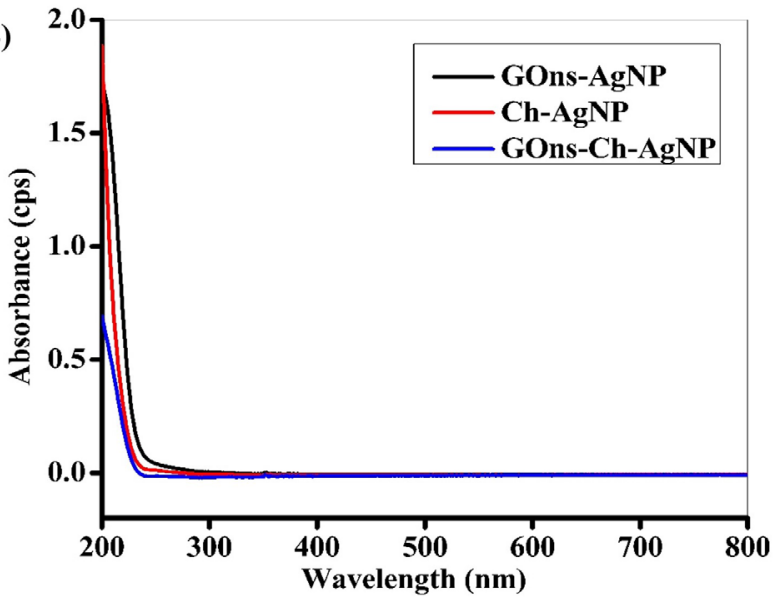

(D)

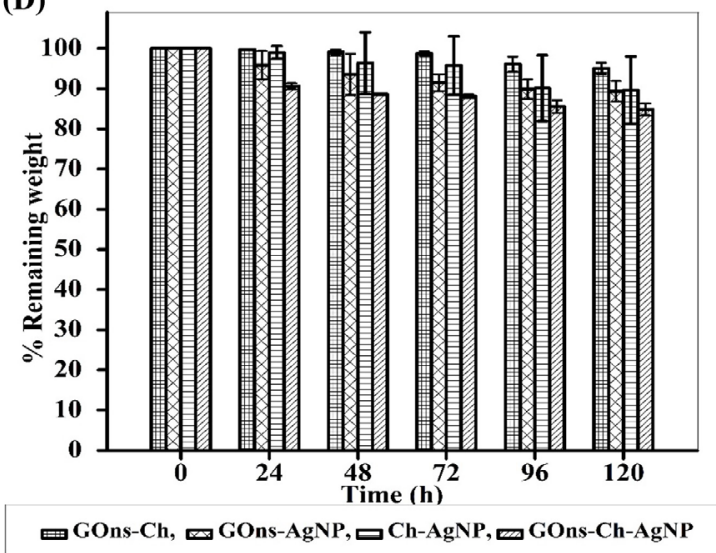

Figure 4. A) Contact angle measurement, B) Silver leaching study, C) Tensile strength analysis and D) Degradation study of all the nano-composites prepared.

\subsubsection{Leaching study of silver nanoparticles from the composites}

The leaching of AgNPs from the composite films into solution was also studied and monitored using UV-Vis spectra. Our result revealed no leaching of AgNPs to the solution after incubation as evidenced by observing no peak in the range of 400- $420 \mathrm{~nm}$ (Fig. 4B). The interaction between oxygen and amide group of GOns and $\mathrm{Ch}$ with AgNPs probably immobilizes nanoparticles in the composite which results in ignorable leaching of AgNPs from the composite films [22]. Therefore, immobilized AgNPs within nano-composite matrix was the 
cause of the stability of the matrix which also helps to prevent bacterial biofilm formation for a long duration due to doped AgNP-based contact killing of bacteria.

\subsubsection{Tensile strength analysis}

Usually higher tensile strength helps to play an important role in reducing surface erosion and abrasion thereby increasing the durability of coating over the material [41] and hence the tensile strength of our composite films was investigated. The tensile strength of GOns-Ch film was increased significantly to $163.04 \mathrm{MPa}$ due to possessing of strong amide linkages between carboxyl groups of GOns and amine groups of chitosan (Fig. 4C) [29]. GOns-AgNP, Ch-AgNP, and GOns-Ch-AgNP showed a tensile strength of 21.01, 43.85 and 27.175 MPa. Such reduction

of tensile strength most probably due to the interaction of AgNPs as a doping agent with the amine functional groups of chitosan and the oxygen functional group of GOns which indeed reduce the strong interaction between GOns and $\mathrm{Ch}$. Hence, to understand further the usability of AgNP doped composite films, we studied degradation of all films.

\subsubsection{Degradation study of composite films}

The degradation of the nanocomposite films was carried out in PBS buffer over time of $120 \mathrm{~h}$ (Fig. 4D). The GOns-Ch-AgNP film degrades little faster than others nano-composite films. Although, all the nano-composite films after $120 \mathrm{~h}$ have lost about only $\sim 10 \%$ of weight with minimal structural deformation due to their higher hydrophobicity prevents lesser absorption water. Hence we can conclude that their high stability prescribes them as a promising material for coating for the long-term usage to prevent the bacterial biofilm formation. 


\subsection{Checking anti-biofilm activity of the composite films}

\subsubsection{Agar plate assay}

The bacterial biofilm inhibition potential of all the nano-composite films was studied against E.coli and B.subtilis by agar plate assay (Fig. 5). The control images displayed the growth of bacteria all over the plate (Fig. 5 A \& D), whereas both E.coli and B.subtilis fails to over all the nano-composite films due to its surface hydrophobicity and anti-adherence property (Fig.5 B-F). A little zone of clearance was noticed surrounding the AgNP impregnated films against E.coli may be due contact killing ability of AgNP $[38,42]$. But no such zone was observed surrounding the AgNP impregnated films against $B$ subtilis. This reduced nanotoxicity may be due to the thicker peptidoglycan layer of Gram-positive bacteria $B$ subtilis [43]. The electrostatic interaction between the bacterial cell wall and the nanoparticle or chitosan may result in the cell wall disruptions $[44,45]$. 

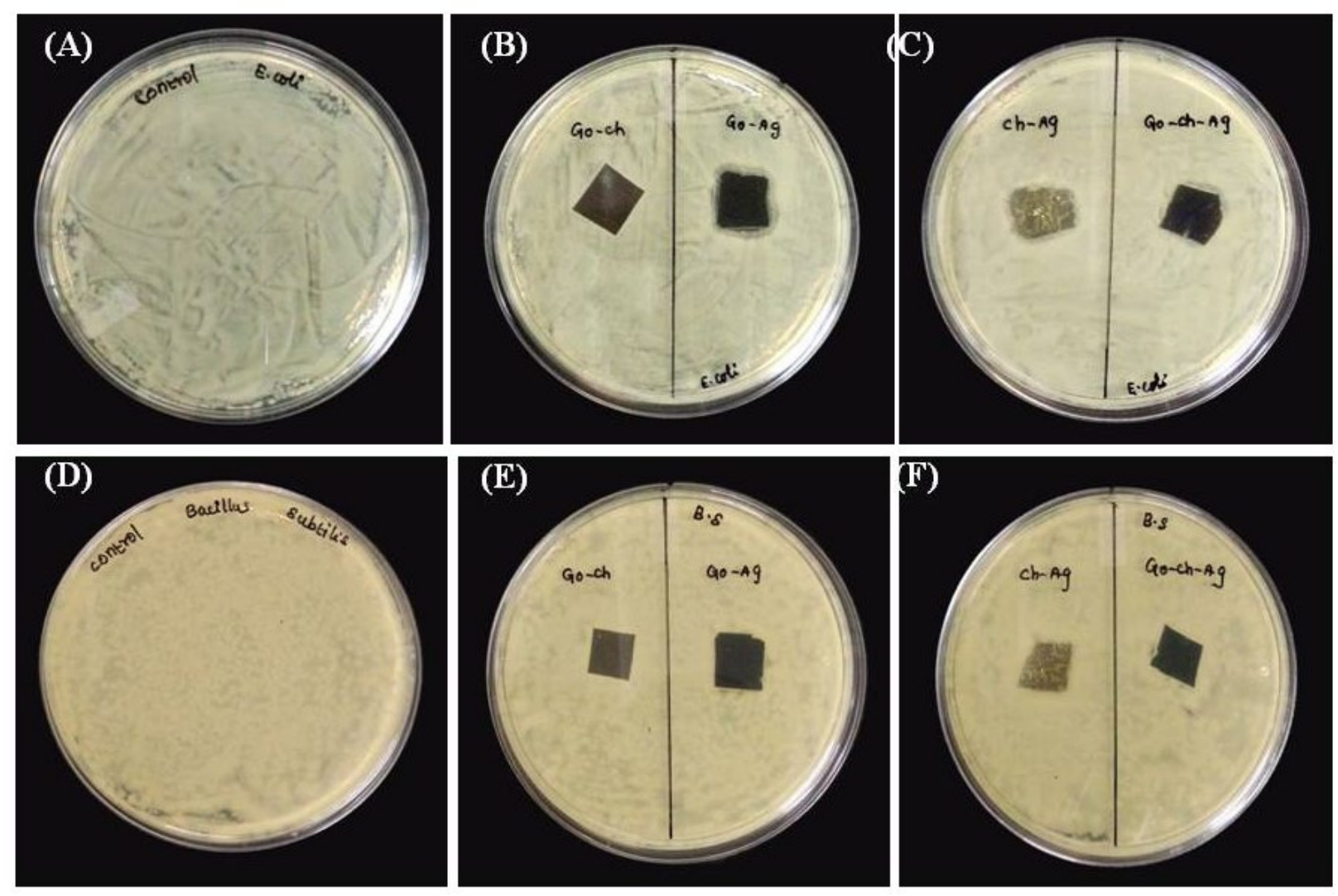

Figure 5. Antibacterial Agar plate assay against E.coli (A-C) and Bacillus subtilis (D-F).

\subsubsection{Congo red assay (Fimbriae generation assay)}

The bacterial biofilm inhibition capability of all our nano-composite films was assessed by congo red plate assay by analyzing the morphology of the colonies for the generation of fimbriae after $48 \mathrm{~h}$ of incubation (Fig. $6 \&$ 7). The morphology of the colony produced over congo red control plate without film (A) showed rugose pink colony structure [46]. This fact was happened due to the absorption of congo red in the agar by the polysaccharide present in the EPS matrix that confirms the formation of biofilm $[3,5]$. In case of all nano-composite films, for both $E$. coil (Fig.6 B-E) and B. subtilis (Fig.7 B-E), there was no rugose pink colony structure as well as the growth of bacteria observed over the film. In GOns-Ch film, such prevention of biofilm 
formation over its surface might be due to its hydrophobic nature while white colony formation surrounding the film indicates that EPS was perhaps not produced and thus inhibited biofilm formation (Fig.6B \& Fig.7B) [47]. Whereas all the other nano-composite films impregnated with AgNPs (GOns-AgNP, Ch-AgNP, and GOns-Ch-AgNP film) prevented the biofilm formation over its surface and their surrounding mainly due to the contact killing property of AgNPs (Fig.6 C-E \& Fig.7 C-E).

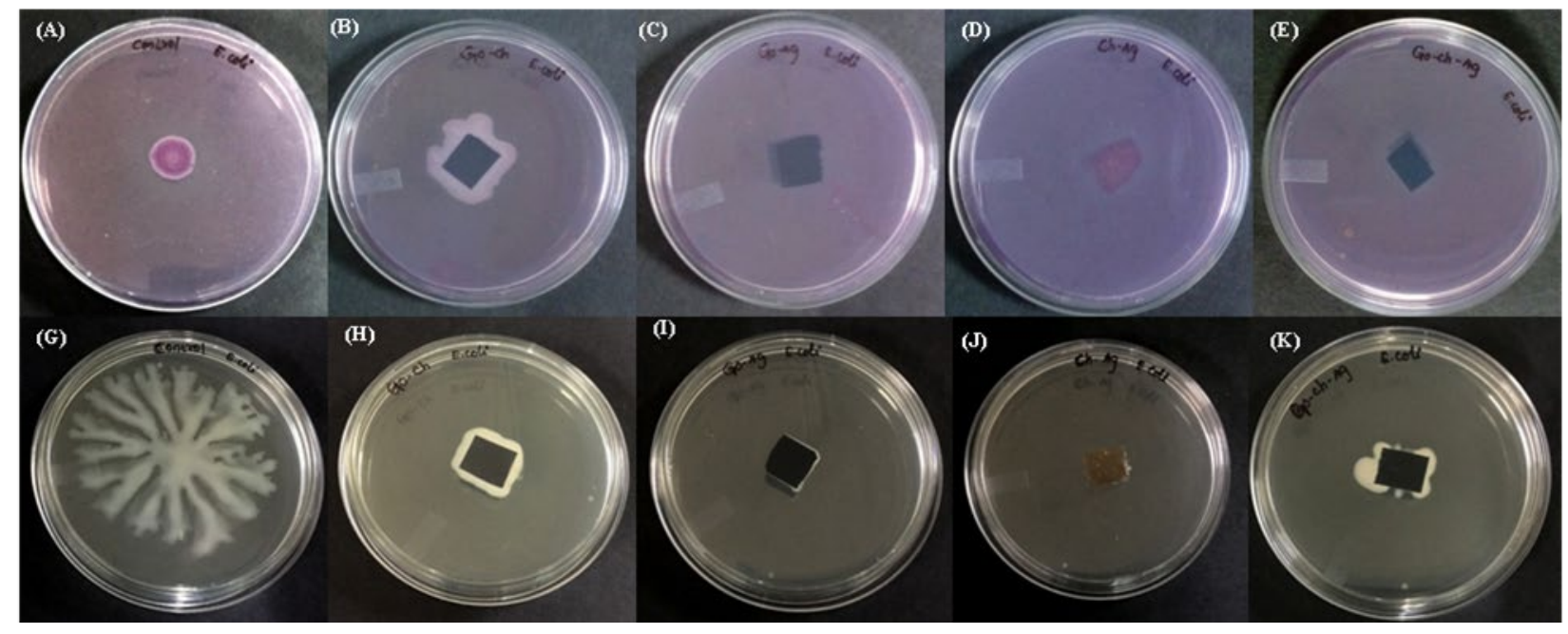

Figure 6. Biofilm inhibition analysis by Fimbriae generation assay against E. coli. A) Control, B) GOns-Ch, C) GOns-AgNP, D) Ch-AgNP and E) GOns-Ch-AgNP film. Swarming pattern analysis by swarming motility assay against $E$. coli. G) Control, H) GOns-Ch, I) GOns-AgNP, J) Ch-AgNP and K) GOns-Ch-AgNP film.

\subsubsection{Swarming motility assay}

The swarming motility of E.coli and B.subtilis was evaluated in the presence of all the composite films (Fig. $6 \&$ 7). In the control (Fig.6G and Fig.7G), both the bacteria formed dendrite-like swarm pattern over the agar plates with the help of pilus surrounding its surface 
[48]. The swarm pattern confirmed the ability of the bacteria to form biofilm over the agar surface. However, swarm pattern was not observed over the surface of all of ours nanocomposite films (Fig. 6H-K and Fig. 7H-K). GOns-Ch only prevents the biofilm formation over its surface which was due to its hydrophobic nature. Whereas, all the other nano-composite films doped with AgNPs (GOns-AgNP, Ch-AgNP, and GOns-Ch-AgNP film) not only prevents the biofilm formation over its surface and but also kills bacteria by contact killing mechanism of AgNPs (see Fig. 6 \& 7). Thus, AgNPs doped films not only inhibited bacterial growth on its surface but also killed bacteria and preventing swarming pattern around the film (Fig. 6I-K and Fig. 7I-K) [42]. But bacteria escaped from the contact of AgNP showed lesser swarm pattern in other nano-composite films doped with AgNPs compared to control and GOns-Ch which also supports the contact killing property of AgNPs.

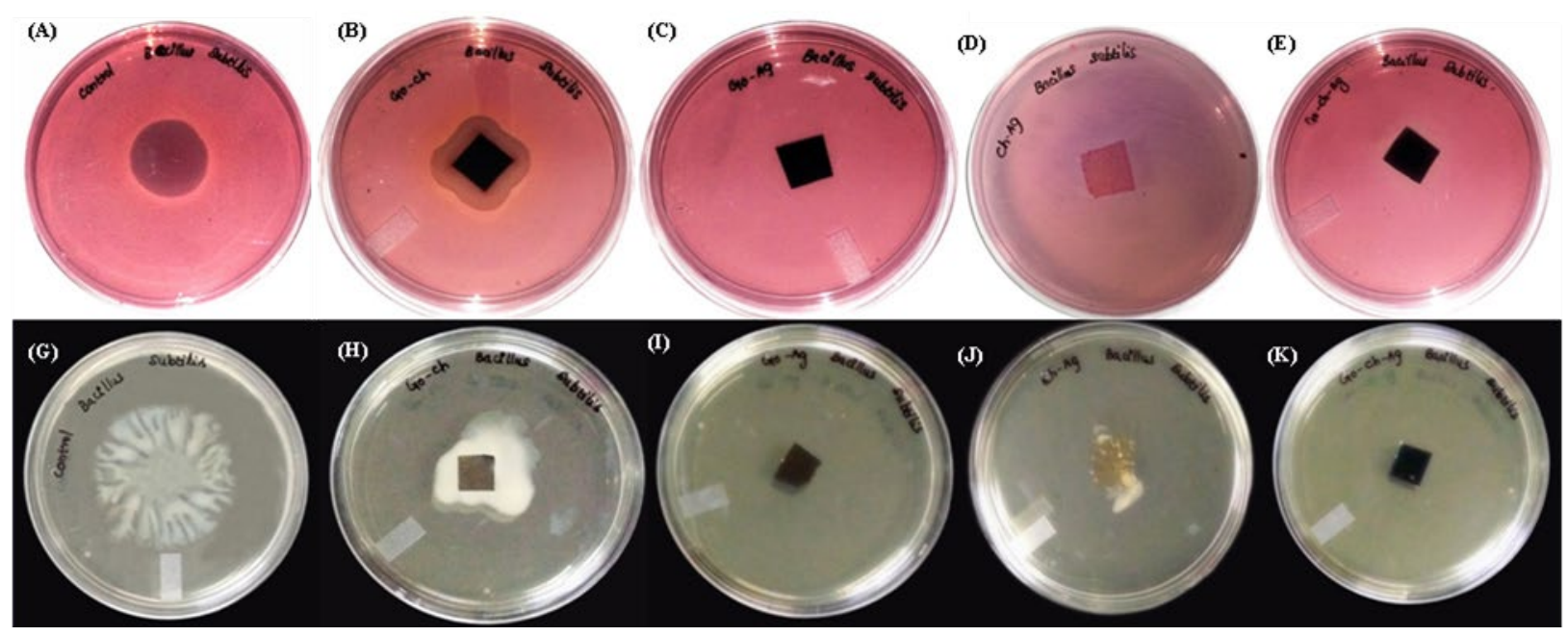

Figure 7. Biofilm formation analysis by Fimbriae generation assay against Bacillus subtilis. (A) Control, (B) GOns-Ch, (C) GOns-AgNP, (D) Ch-AgNP and (E) GOns-Ch-AgNP film. Swarming pattern analysis by swarming motility assay against B. subtilis. (G) Control, (H) GOnsCh, (I) GOns-AgNP, (J) Ch-AgNP and (K) GOns-Ch-AgNP film. 


\subsubsection{Biofilm static assay}

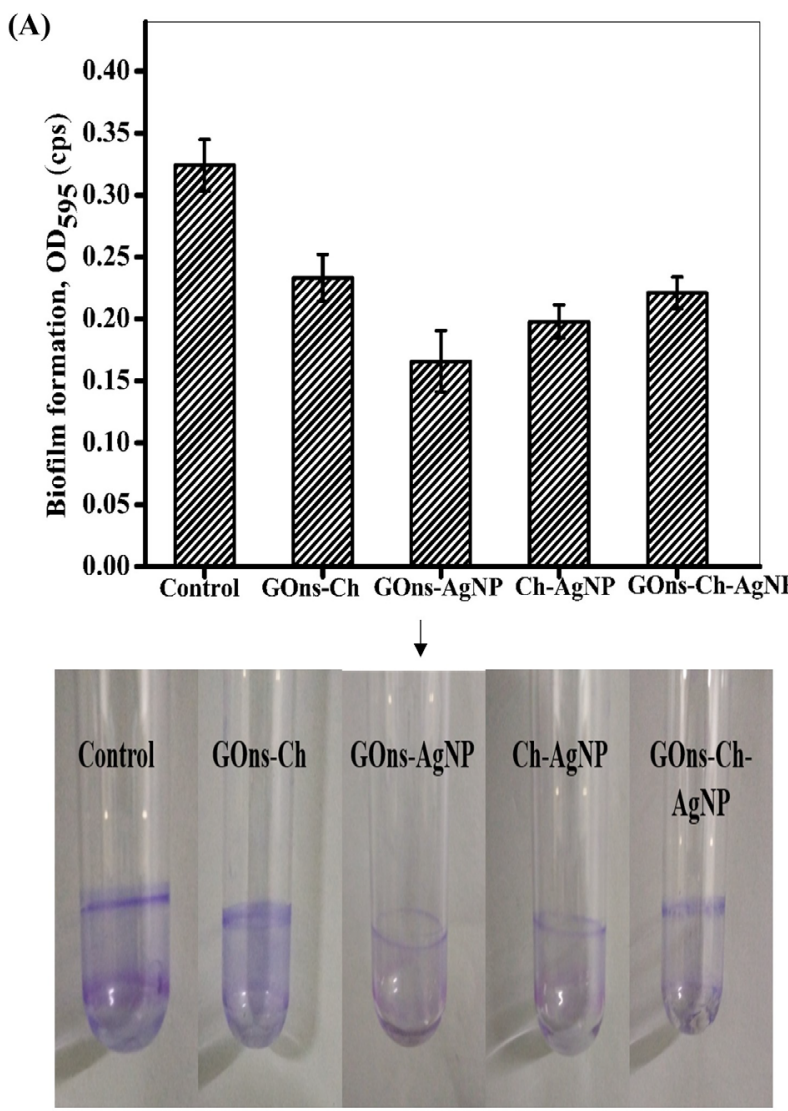

(B)
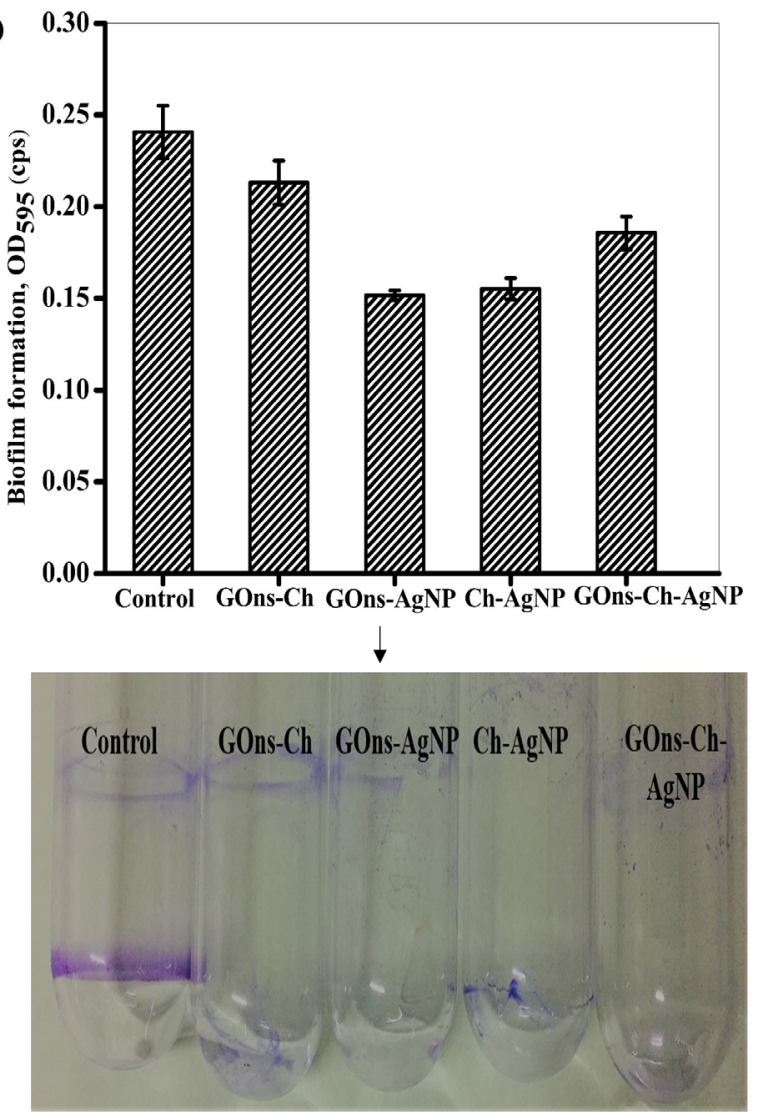

Figure 8. Quantification of biofilm formation by A) E.coli \& B) B. subtilis in the presence of nanocomposite.

The indirect quantification of biofilm formation by E.coli and B. subtilis on various nano-composites films was also studied using biofilm static assay as described in 'Materials and Methods' section (Fig. 8). The biofilm formation was found highest in the control over the test tube glass surface (as evidenced by crystal violet dye binding to biofilm EPS) compared to those containing nanocomposite sample material of $2 \times 1 \mathrm{~cm}$ dimension [49]. Results revealed that the biofilm deposition in 
the presence of nanocomposites on the glass tube was lesser than the control for both the bacteria. Such inhibition of bacterial growth perhaps due to ROS mediated oxidative stress generated by both GOns and AgNPs as well as also by positively charged chitosan polymer which has also intrinsic antibacterial property that can disrupt the cell wall of negatively charged bacteria (Fig.8A \& B) [9, 16, 17, 38, 42, 44]. However, all films prepared with AgNP doping demonstrated reduced biofilm deposition on the glass surface. The results indicate that nanocomposites specifically doped with AgNPs inhibited bacterial growth on the solid surface.

\subsection{Assessment of anti-adhesion property of nano-composites by FESEM}

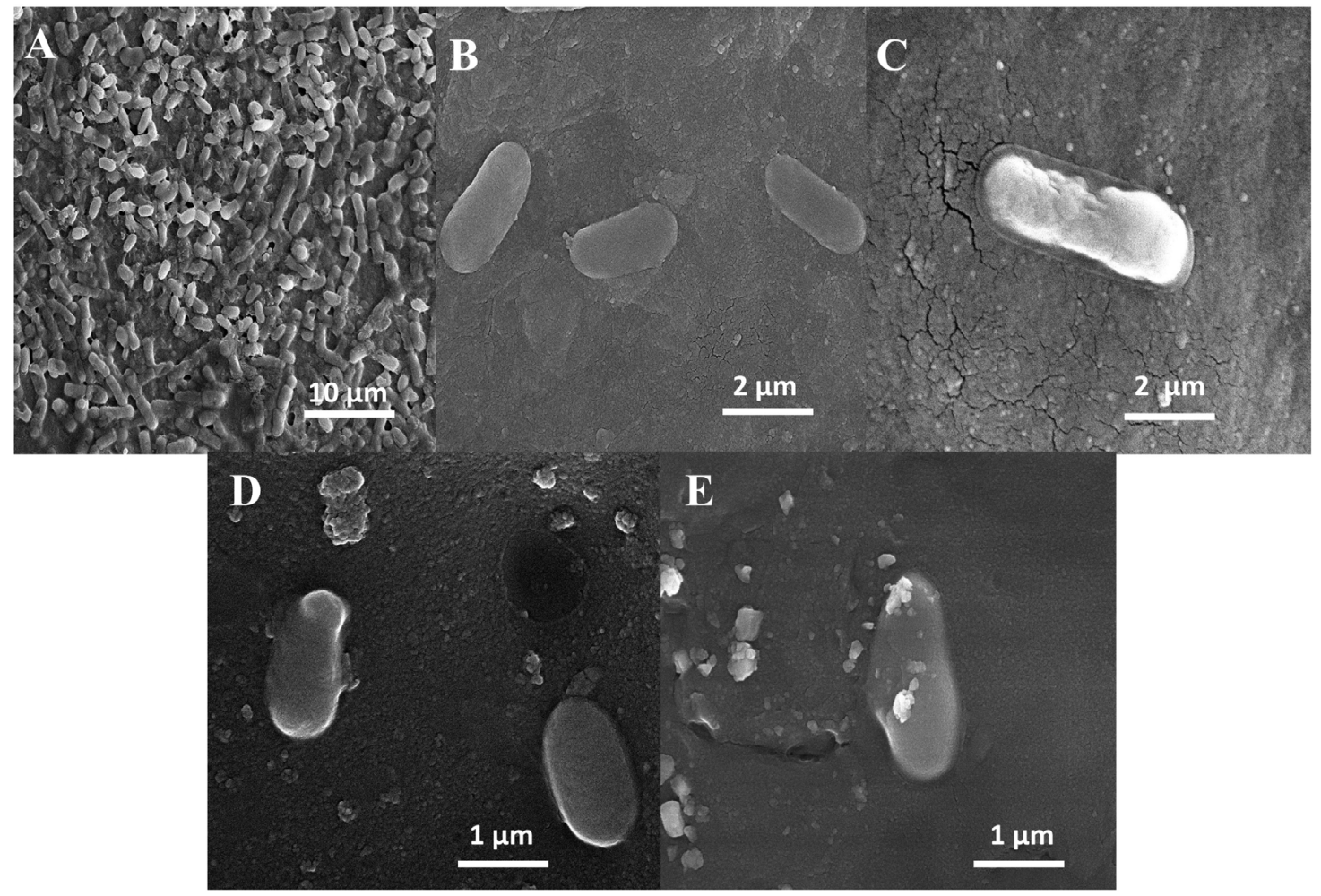

Figure 9. FESEM images of E.coli bacteria attached over A) Control surface, B) GOns-Ch film, C) GOns-AgNP film, D) Ch-AgNP film and E) GOns-Ch-AgNP film. 
The biofilm formation and bacterial morphology over the surface of the films were analyzed by FESEM image analysis (Fig. 9 \&10). The control image (Fig.9A \& Fig.10A) clearly showed the formation of biofilm whereas no such biofilm formation was observed over the surface of all nano-composite films (Fig. 9B-E). Although GOns-Ch film (Fig.9B \& Fig.10B) showed the individual attachment of bacteria on its surface, AgNP impregnated films (Fig.9 C-E \& Fig.10 C-E) demonstrated higher inhibition to cell attaching. Such inhibition probably was via disintegration of bacterial cell wall through the generation of reactive oxygen species (ROS) induced by silver nanoparticles [49].

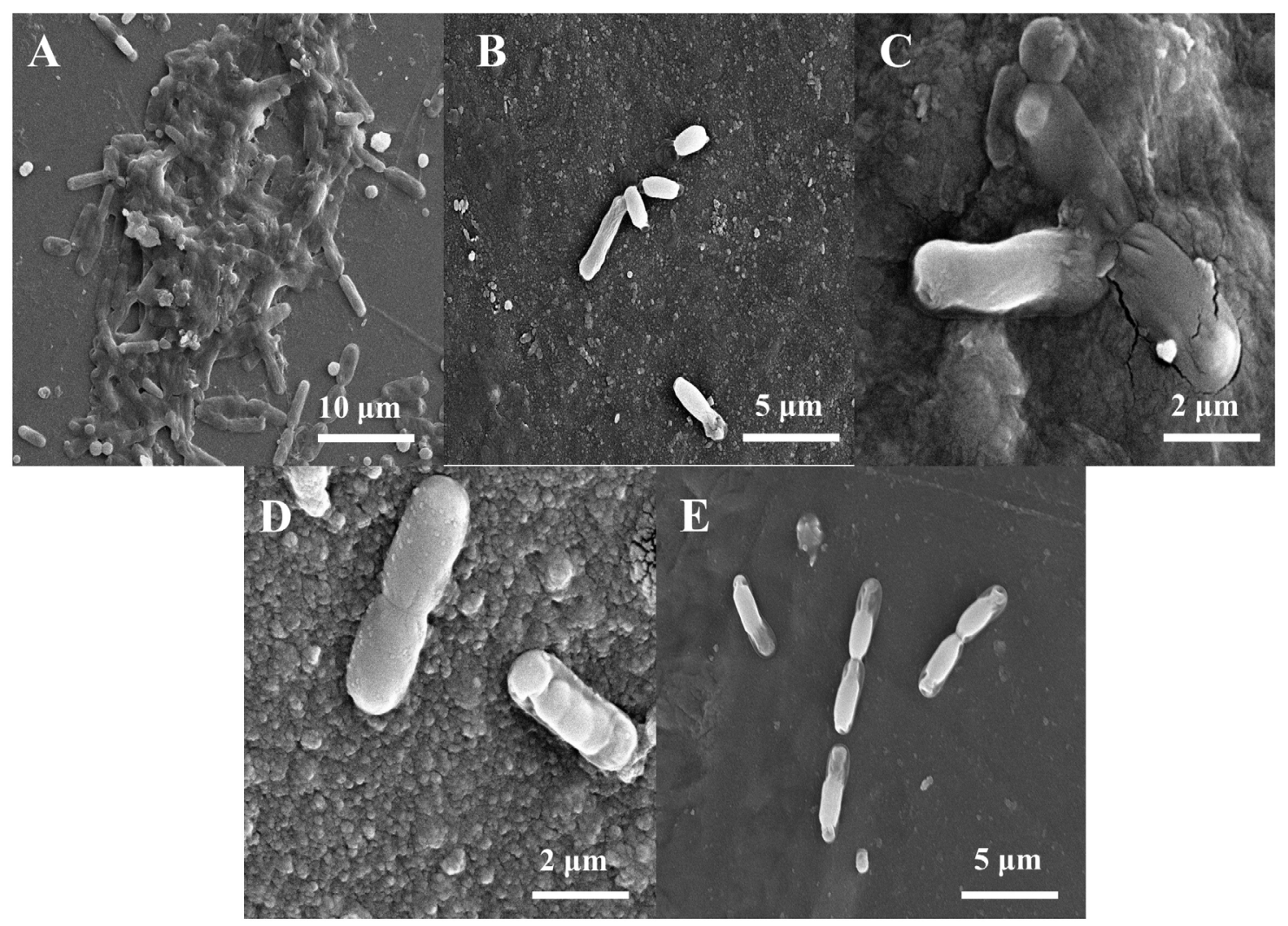

Figure 10. FESEM images of Bacillus subtilis bacteria attached over A) Control surface, B) GOns-Ch, C) GOns-AgNP, D) Ch-AgNP and E) GOns-Ch-AgNP film. 
While the anti-bacterial property of AgNP is well known [38, 42], evidence of such properties has also been documented for GOns as well $[16,17]$. Therefore, the use of both the materials not only provides film stability or strength (from GOns) but also exhibit excellent inhibitory effect of biofilm forming bacterial growth. Indeed there is few repots on the anti- bacterial activity of nanocomposites consisting of chitosan, AgNPs and graphene oxide. Dawei et al., (year) have prepared nanocomposite film of chitosan and graphene oxide film anti- bacterial activity against Bacillus subtilis with inhibition of 2.74-3.48 mm. Liu et al. (year) synthesized GO-Ag powder which demonstrated the inhibition of Staphylococcus aureus and Pseudomonas aeruginosa. Jing et al. (year) synthesized colloidal solution of rGO-Ch-Ag and checked its antimicrobial and catalytic effect. Recently Marta et al. also reported chitosan-silver nanoparticles-graphene oxide nano hybrids that exhibited antibacterial activity against Bacillus subtilis, however, the antibiofilm activity of such nanocomposite was not explored [36]. To our knowledge, people have worked with nanocomposite consisting of chitosan, AgNPs and graphene oxide in colloidal or powders form and demonstrated an antibacterial activity against only liquid bacterial culture. Furthermore, Biofilm forming bacterial have more resistant due to formation of protective layer called extracellular polymeric substances (EPS) [3, 5]. Hence in the present study, we impregnated silver nanoparticles in GOns-Ch to improve the antibacterial activity and demonstrated that Ours GOns-Ch-AgNP works in dual mechanistic way in inhibiting the biofilm formation. Firstly, GOns-Ch-AgNP nanocomposite film has anti-adhesion property due to its surface hydrophobicity. Secondly, GOns-Ch-AgNP nanocomposite film have contact killing ability due to impregnated silver nanoparticles. Furthermore, GOns-Ch-AgNP nanocomposite film possess high tensile strength make it as a good candidate as coating material for industrial setup to inhibit biofouling.

\section{Conclusion}

In our present investigation, we fabricated four composite films by facile and environmentally friendly methods possessing of biofilm-inhibiting activity against both Escherichia coli and Bacillus subtilis to assess its ability in restraining biofouling. The various assays confirmed that all the composite films exhibited contact inhibition of bacterial growth to a different extent and 
such growth was only found in the surrounding of GOns-Ch film, however it prevented adhesion of bacterial species over its surface. Despite that, ignorable growth was observed surrounding to the AgNP impregnated films (GOns-AgNP, Ch-AgNP \& GOns-Ch-AgNP) which inferred that doping of AgNP plays an important role in capture killing of bacteria, thus hampers biofilm formation. Considering the properties such as excellent hydrophobicity, durability, and antibacterial activity, our GOns-Ch-AgNP composite film demonstrated strong anti-biofilm or biofouling properties which might be used as a promising surface coating material in various industrial set ups including biocidal paints and glass coatings as well as domestic setups to forbid biofouling.

\section{Acknowledgments}

The authors sincerely thank the Science and Engineering Research Board, Government of India, for financial support (Grant No. SERB/F/4290/2016-17) and National Institute of Technology Rourkela, Government of India, for providing the infrastructural facility for carrying out this work.

\section{Supporting Information}

Photographic images of A) Base components and B) Composites solution (Figure S1).

\section{Disclosure statement}

No potential conflict of interest was reported by the authors.

\section{Reference}


[1] S. Qayyum, A.U. Khan, Nanoparticles vs. biofilms: a battle against another paradigm of antibiotic resistance, MedChemComm, 7 (2016) 1479-1498.

[2] I. Banerjee, R.C. Pangule, R.S. Kane, Antifouling coatings: recent developments in the design of surfaces that prevent fouling by proteins, bacteria, and marine organisms, Advanced Materials, 23 (2011) 690-718.

[3] A.F. de Faria, D.S.T. Martinez, S.M.M. Meira, A.C.M. de Moraes, A. Brandelli, A.G. Souza Filho, O.L. Alves, Anti-adhesion and antibacterial activity of silver nanoparticles supported on graphene oxide sheets, Colloids and Surfaces B: Biointerfaces, 113 (2014) 115-124.

[4] R. Van Houdt, C.W. Michiels, Biofilm formation and the food industry, a focus on the bacterial outer surface, Journal of applied microbiology, 109 (2010) 1117-1131.

[5] W. Shao, X. Liu, H. Min, G. Dong, Q. Feng, S. Zuo, Preparation, characterization, and antibacterial activity of silver nanoparticle-decorated graphene oxide nanocomposite, ACS applied materials \& interfaces, 7 (2015) 6966-6973.

[6] M. Monte-Serrano, P. Fernandez-Saiz, R. Ortí-Lucas, B. Hernando, Effective Antimicrobial Coatings Containing Silver-Based Nanoclays and Zinc Pyrithione, J Microb Biochem Technol, 7 (2015).

[7] M. Cloutier, D. Mantovani, F. Rosei, Antibacterial coatings: challenges, perspectives, and opportunities, Trends in biotechnology, 33 (2015) 637-652.

[8] R. Dastjerdi, M. Montazer, A review on the application of inorganic nano-structured materials in the modification of textiles: focus on anti-microbial properties, Colloids and Surfaces B: Biointerfaces, 79 (2010) 5-18.

[9] E.I. Rabea, M.E.-T. Badawy, C.V. Stevens, G. Smagghe, W. Steurbaut, Chitosan as antimicrobial agent: applications and mode of action, Biomacromolecules, 4 (2003) 1457-1465.

[10] D. Wei, W. Sun, W. Qian, Y. Ye, X. Ma, The synthesis of chitosan-based silver nanoparticles and their antibacterial activity, Carbohydrate research, 344 (2009) 2375-2382.

[11] H. Lim, N. Huang, C. Loo, Facile preparation of graphene-based chitosan films: Enhanced thermal, mechanical and antibacterial properties, Journal of Non-Crystalline Solids, 358 (2012) 525-530. 
[12] S. Bhuvaneshwari, D. Sruthi, V. Sivasubramanian, K. Niranjana, J. Sugunabai, Development and characterization of chitosan films, IJERA, 1 (2011) 292-299.

[13] M. Huang, H. Tu, J. Chen, R. Liu, Z. Liang, L. Jiang, et al., Chitosan-rectorite nanospheres embedded aminated polyacrylonitrile nanofibers via shoulder-to-shoulder electrospinning and electrospraying for enhanced heavy metal removal, Applied Surface Science. 437 (2018) 294303.

[14] J. Chen, X. Shi, Y. Zhan, X. Qiu, Y. Du, H. Deng, Construction of horizontal stratum landform-like composite foams and their methyl orange adsorption capacity, Applied Surface Science. 397 (2017) 133-143.

[15] R. Huang, W. Li, X. Lv, Z. Lei, Y. Bian, H. Deng, et al., Biomimetic LBL structured nanofibrous matrices assembled by chitosan/collagen for promoting wound healing, Biomaterials. 53 (2015) 58-75.

[16] K. Krishnamoorthy, N. Umasuthan, R. Mohan, J. Lee, S.-J. Kim, Antibacterial activity of graphene oxide nanosheets, Science of Advanced Materials, 4 (2012) 1111-1117.

[17] S. Liu, T.H. Zeng, M. Hofmann, E. Burcombe, J. Wei, R. Jiang, J. Kong, Y. Chen, Antibacterial activity of graphite, graphite oxide, graphene oxide, and reduced graphene oxide: membrane and oxidative stress, ACS nano, 5 (2011) 6971-6980.

[18] R. Pasricha, S. Gupta, A.K. Srivastava, A Facile and Novel Synthesis of AgGraphene-Based Nanocomposites, Small, 5 (2009) 2253-2259.

[19] Y. Liu, J. Wen, Y. Gao, T. Li, H. Wang, H. Yan, et al., Antibacterial graphene oxide coatings on polymer substrate, Applied Surface Science. 436 (2018) 624-630.

[20] S. Yang, P. Lei, Y. Shan, D. Zhang, Preparation and characterization of antibacterial electrospun chitosan/poly (vinyl alcohol)/graphene oxide composite nanofibrous membrane, Applied Surface Science. 435 (2018) 832-840.

[21] D. Zhang, S. Yang, Y. Chen, S. Liu, H. Zhao, J. Gu, 60Co $\gamma$-ray Irradiation Crosslinking of Chitosan/Graphene Oxide Composite Film: Swelling, Thermal Stability, Mechanical, and Antibacterial Properties, Polymers. 10 (2018) 294.

[22] X. Yang, Y. Tu, L. Li, S. Shang, X.-m. Tao, Well-dispersed chitosan/graphene oxide nanocomposites, ACS applied materials \& interfaces, 2 (2010) 1707-1713. 
[23] Alshareef, K. Laird, R. Cross, Shape-dependent antibacterial activity of silver nanoparticles on Escherichia coli and Enterococcus faecium bacterium, Applied Surface Science. 424 (2017) 310-315.

[24] T. Vi, S.R. Kumar, B. Rout, C.-H. Liu, C.-B. Wong, C.-W. Chang, et al., The Preparation of Graphene Oxide-Silver Nanocomposites: The Effect of Silver Loads on Gram-Positive and Gram-Negative Antibacterial Activities, Nanomaterials. 8 (2018) 163.

[25] J. An, G. Guo, R. Yin, Q. Luo, X. Li, F. Liu, et al., Facile preparation of silver/reduced graphene oxide/chitosan colloid and application of the nanocomposite in antibacterial and catalytic activity, Polymer International. 67 (2018) 515-527.

[26] L. Shahriary, A.A. Athawale, Graphene oxide synthesized by using modified hummers approach, Int. J. Renew. Energy Environ. Eng, 2 (2014) 58-63.

[27] D.K. Ban, S. Paul, Protein corona over silver nanoparticles triggers conformational change of proteins and drop in bactericidal potential of nanoparticles: Polyethylene glycol capping as preventive strategy, Colloids and Surfaces B: Biointerfaces, 146 (2016) 577-584.

[28] C.-M. Chen, J.-Q. Huang, Q. Zhang, W.-Z. Gong, Q.-H. Yang, M.-Z. Wang, Y.-G. Yang, Annealing a graphene oxide film to produce a free standing high conductive graphene film, Carbon, 50 (2012) 659-667.

[29] D. Han, L. Yan, W. Chen, W. Li, Preparation of chitosan/graphene oxide composite film with enhanced mechanical strength in the wet state, Carbohydrate Polymers, 83 (2011) 653-658.

[30] K.P. Lemon, D.E. Higgins, R. Kolter, Flagellar motility is critical for Listeria monocytogenes biofilm formation, Journal of Bacteriology, 189 (2007) 4418-4424.

[31] X.-F. Sun, J. Qin, P.-F. Xia, B.-B. Guo, C.-M. Yang, C. Song, S.-G. Wang, Graphene oxide-silver nanoparticle membrane for biofouling control and water purification, Chemical Engineering Journal, 281 (2015) 53-59.

[32] T.N. Blanton, D. Majumdar, Characterization of X-ray irradiated graphene oxide coatings using X-ray diffraction, X-ray photoelectron spectroscopy, and atomic force microscopy, Powder Diffraction, 28 (2013) 68-71. 
[33] M. Mehrali, E. Sadeghinezhad, S.T. Latibari, S.N. Kazi, M. Mehrali, M.N.B.M. Zubir, H.S.C. Metselaar, Investigation of thermal conductivity and rheological properties of nanofluids containing graphene nanoplatelets, Nanoscale research letters, 9 (2014) 15.

[34] A. Hebeish, T.I. Shaheen, M.E. El-Naggar, Solid state synthesis of starch-capped silver nanoparticles, International journal of biological macromolecules, 87 (2016) 70-76.

[35] L. Huang, H. Yang, Y. Zhang, W. Xiao, Study on Synthesis and Antibacterial Properties of Ag NPs/GO Nanocomposites, Journal of Nanomaterials, 2016 (2016).

[36] B. Marta, M. Potara, M. Iliut, E. Jakab, T. Radu, F. Imre-Lucaci, G. Katona, O. Popescu, S. Astilean, Designing chitosan-silver nanoparticles-graphene oxide nanohybrids with enhanced antibacterial activity against Staphylococcus aureus, Colloids and Surfaces A: Physicochemical and Engineering Aspects, 487 (2015) 113-120.

[37] Y. Pan, T. Wu, H. Bao, L. Li, Green fabrication of chitosan films reinforced with parallel aligned graphene oxide, Carbohydrate polymers, 83 (2011) 1908-1915.

[38] J.S. Kim, E. Kuk, K.N. Yu, J.-H. Kim, S.J. Park, H.J. Lee, S.H. Kim, Y.K. Park, Y.H. Park, C.-Y. Hwang, Antimicrobial effects of silver nanoparticles, Nanomedicine: Nanotechnology, Biology and Medicine, 3 (2007) 95-101.

[39] Y. Yuan, M.P. Hays, P.R. Hardwidge, J. Kim, Surface characteristics influencing bacterial adhesion to polymeric substrates, RSC Advances, 7 (2017) 14254-14261.

[40] E.J. Falde, S.T. Yohe, Y.L. Colson, M.W. Grinstaff, Superhydrophobic materials for biomedical applications, Biomaterials, 104 (2016) 87-103.

[41] B. Bhushan, Overview of Coating Materials, Surface Treatments, and Screening Techniques for Tribological Applications-Part 1: Coating Materials and Surface Treatments, Testing of Metallic and Inorganic Coatings, ASTM International1987.

[42] A. Dror-Ehre, H. Mamane, T. Belenkova, G. Markovich, A. Adin, Silver nanoparticle-E. coli colloidal interaction in water and effect on E. coli survival, Journal of Colloid and Interface Science, 339 (2009) 521-526. 
[43] R. Sinha, R. Karan, A. Sinha, S. Khare, Interaction and nanotoxic effect of $\mathrm{ZnO}$ and Ag nanoparticles on mesophilic and halophilic bacterial cells, Bioresource technology, 102 (2011) 1516-1520.

[44] R.C. Goy, S.T. Morais, O.B. Assis, Evaluation of the antimicrobial activity of chitosan and its quaternized derivative on E. coli and S. aureus growth, Revista Brasileira de Farmacognosia, 26 (2016) 122-127.

[45] P. Sanpui, A. Murugadoss, P.D. Prasad, S.S. Ghosh, A. Chattopadhyay, The antibacterial properties of a novel chitosan-Ag-nanoparticle composite, International journal of food microbiology, 124 (2008) 142-146.

[46] A. Ueda, T.K. Wood, Connecting quorum sensing, c-di-GMP, pel polysaccharide, and biofilm formation in Pseudomonas aeruginosa through tyrosine phosphatase TpbA (PA3885), PLoS pathogens, 5 (2009) e1000483.

[47] J.D. Brooks, S.H. Flint, Biofilms in the food industry: problems and potential solutions, International journal of food science \& technology, 43 (2008) 2163-2176.

[48] W.M. Dunne, Bacterial adhesion: seen any good biofilms lately?, Clinical microbiology reviews, 15 (2002) 155-166.

[49] N. Durán, P.D. Marcato, R.D. Conti, O.L. Alves, F. Costa, M. Brocchi, Potential use of silver nanoparticles on pathogenic bacteria, their toxicity and possible mechanisms of action, Journal of the Brazilian Chemical Society, 21 (2010) 949-959. 